\title{
THE STUDY OF THE ANTIHYPOXIC ACTION OF 1-PHENETHYL-5,7-DIHYDRO-1H-PYRROLO- [2,3-d]PYRIMIDIN-2,4,6-TRIONE (DEZAPUR) ON DIFFERENT MODELS OF HYPOXIA
}

\author{
O.V.Sevryukov, V.A.Volkovoy, O.V.Kolisnyk, K.M.Sytnik \\ National University of Pharmacy \\ Key words: hypoxia; 1-phenethyl-5,7-dihydro-1H-pyrrolo-[2,3-d]pyrimidin-2,4,6-trione; \\ antihypoxant drug Mexidol
}

\begin{abstract}
Extension of hypoxic states is a consequence of disorder of cerebral, coronary and peripheral circulation, and it requires further search for substances that can reduce the negative effect of hypoxia on tissues, and increase their resistance to hypoxia. The study of the antihypoxic activity of 1-phenethyl5,7-dihydro-1H-pyrrolo-[2,3-d]pyrimidin-2,4,6-trione under the conditional name of Dezapur on different models of hypoxia (hemic, hypercapnic, histotoxic and hypobaric) has been presented. The reference drug is Mexidol. Dezapur in the dose of $10 \mathrm{mg} / \mathrm{kg}$ and Mexidol in the dose of $100 \mathrm{mg} / \mathrm{kg}$ show the expressed antihypoxic activity on all models of hypoxia compared to the control group: hemic hypoxia in 2.09 and 1.82 times, hypercapnic hypoxia - in 2.35 and 2.29 times, on histotoxic hypoxia in 2.04 and 1.9 times, hypobaric hypoxia - in 3.06 and 2.72 times, respectively.
\end{abstract}

Hypoxia is a pathological process, which is characterized by decrease of the oxygen content in the blood and tissues, development of the complex of the secondary non-specific metabolic and functional disorders, as well as the reaction of adaptation [1]. Extension of hypoxic states is a consequence of disorder of cerebral, coronary and peripheral circulation, and it requires further search for substances that can reduce the negative effect of hypoxia on tissues, and increase their resistance to hypoxia. Therefore, the search of such substances that would increase the resistance of tissues to hypoxia, bind free radicals formed as a result of hypoxia, i.e. having the antioxidant effect and reducing inflammatory edema, is a topical issue of medical chemistry $[2,5]$.

The study of active antihypoxant drugs is a current problem in pharmacology. Thus, the screening studies of 1-phenethyl-5,7-dihydro-1H-pyrrolo-[2,3-d]pyrimidin-2,4,6-trione (Dezapur), which can be a potential antioxidant drug, have been conducted [3].

\section{Materials and Methods}

The antihypoxic activity was studied on nonlinear white male mice weighing $20 \pm 2 \mathrm{~g}$. The test substance in the dose of $1 / 10$ of its $\mathrm{LD}_{50}$ and the reference drug Mexidol in the dose of $100 \mathrm{mg} / \mathrm{kg}\left(\mathrm{ED}_{50}\right)$ were introduced intragastrically $30 \mathrm{~min}$ prior to the experiment. Control and experiments were performed simultaneously and recorded the life time in minutes [7]. All animals were divided into 3 groups, each group of 6 animals: group 1 - intact animals received distilled water in the volume of $1 \mathrm{ml}$; group 2 - animals received Dezapur in the effective dose of $10 \mathrm{mg} / \mathrm{kg}$; group 3 - animals received the reference drug Mexidol [6,9].

The acute hypobaric hypoxia was created by raising animals to the height of $11.000 \mathrm{~m}$ and with the speed of $50 \mathrm{~m} / \mathrm{s}$ in the Komovsky apparatus; the acute hypoxic hypoxia - by placing animals in a $200 \mathrm{ml}$ airtight chamber; the hemic acute hypoxia - by subcutaneous injection of sodium nitrite in the dose of $225 \mathrm{mg} / \mathrm{kg}$; the histotoxic hypoxia - by intraperitoneal introduction of sodium nitroprusside in the dose of $25 \mathrm{mg} / \mathrm{kg}$. The antihypoxic action was assessed by duration of the animals' life. The results of the study were compared with the reference drug Mexidol widely known in medical practice as an antihypoxant and antioxidant drug $[4,8,10]$.

\section{Results and Discussion}

According to the results obtained Dezapur exhibited a stable antihypoxic activity by the life expectancy of the animals on all experimental models (Table, Fig.). Its prophylactic introduction prolonged the life of mice in 2.0-3.1 times compared to the control group.

On the experimental models of the acute normobaric hypoxia and the acute histotoxic hypoxia the antihypoxic activity of Dezapur and Mexidol was almost identical. When introducing Dezapur on these models of hypoxia the life of animals was 2.5 and 2.1 times longer, and it was not significantly different from the indicators of Mexidol (2.4 and 2.0 times, respectively). The results obtained are statistically unreliable $(\mathrm{p}>0.05)$.

In the acute hemic hypoxia the efficiency of Dezapur exceeded the similar effect of the reference drug in 1.19 times. The life of animals was 1.97 times longer when introducing Dezapur and 1.65 times longer when introducing Mexidol.

Dezapur and Mexidol showed the highest antihypoxic activity in relation to the control group on the model of the acute hypobaric hypoxia. At the same time the efficiency of Dezapur was 1.13 times higher than that of Mexidol by the life expectancy in mice.

The data obtained concerning Mexidol coincide with the results of other authors $[6,9]$. 
The effect of Dezapur on the survival of white mice under conditions of different models of hypoxia $(M \pm m), n=6$

\begin{tabular}{|l|c|c|c|c|}
\hline $\begin{array}{c}\text { Conditions of } \\
\text { the experiment }\end{array}$ & $\begin{array}{c}\text { Acute hemic hypoxia, } \\
\min \end{array}$ & $\begin{array}{c}\text { Normobaric } \\
\text { hypercapnic hypoxia, } \\
\min \end{array}$ & $\begin{array}{c}\text { Acute histotoxic } \\
\text { hypoxia, min }\end{array}$ & $\begin{array}{c}\text { Acute hypobaric } \\
\text { hypoxia, min }\end{array}$ \\
\hline Dezapur & $27.38 \pm 0.72^{*}$ & $31.22 \pm 0.21^{*}$ & $12.82 \pm 0.52^{*}$ & $21.97 \pm 0.58^{*}$ \\
\hline Mexidol & $23.82 \pm 0.61^{*}$ & $30.40 \pm 0.26^{*}$ & $11.95 \pm 0.42^{*}$ & $19.51 \pm 0.72^{*}$ \\
\hline Control & $13.11 \pm 0.73$ & $13.33 \pm 0.61$ & $6.28 \pm 0.96$ & $7.18 \pm 0.25$ \\
\hline
\end{tabular}

Notes: ${ }^{*}-p<0.05$ compared to the control group. The survival of control animals is taken as $100 \%$.

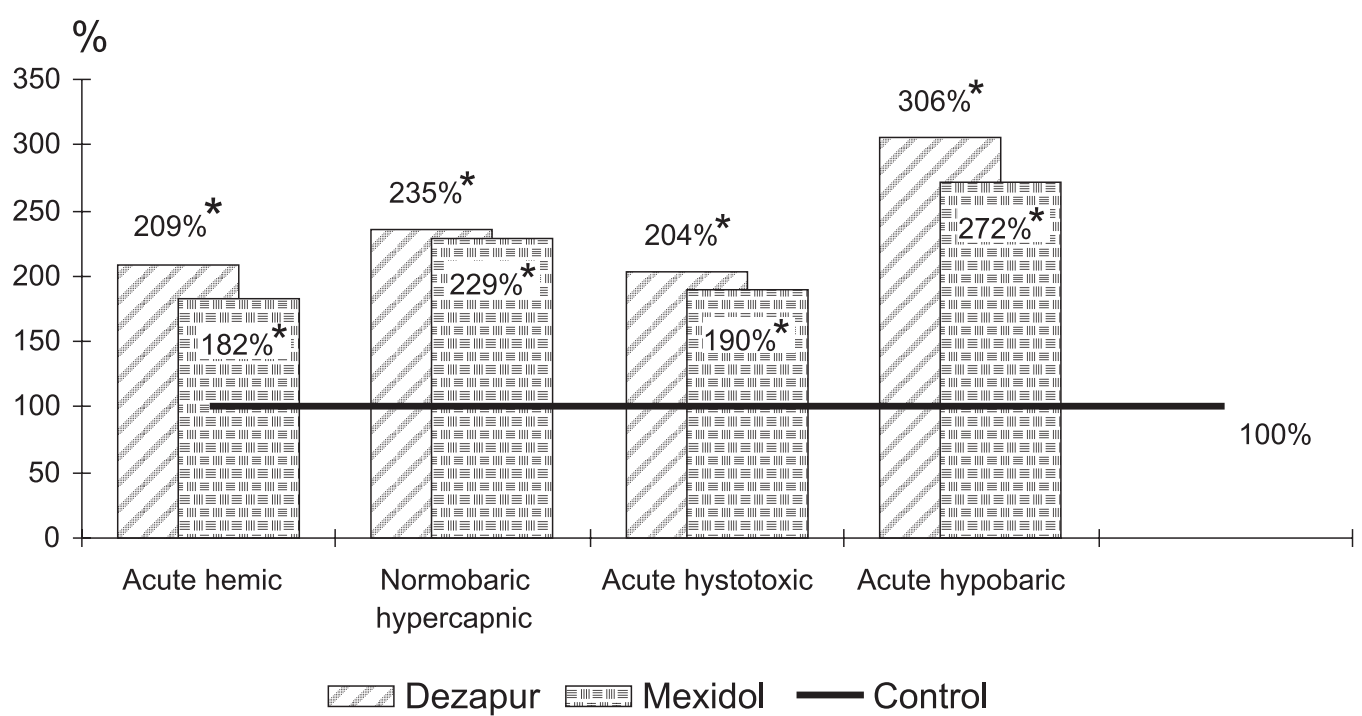

Fig. Duration of the animals' life under conditions of different types of the acute hypoxia in prophylactic introduction of Dezapur, \%: $*-p<0.05$ compared to the control group.

The data obtained indicate that Dezapur in the dose of $10 \mathrm{mg} / \mathrm{kg}$ and Mexidol in the dose of $100 \mathrm{mg} / \mathrm{kg}$ show the expressed antihypoxic activity on all models of hypoxia compared to the control group: hemic hypoxia in 2.09 and 1.82 times, hypercapnic hypoxia - in 2.35 and 2.29 times, on histotoxic hypoxia - in 2.04 and 1.9 times, hypobaric hypoxia - in 3.06 and 2.72 times, respectively.

\section{CONCLUSIONS}

Under conditions of hemic, normobaric, histotoxic and hypobaric hypoxia (in white mice) Dezapur $(10 \mathrm{mg} / \mathrm{kg}$, single intragastric introduction) significantly prolongs the life of animals in $2.1 ; 2.0 ; 2.4 ; 3.1$ times, respective$1 y$, and in this respect it is not inferior to the reference drug Mexidol. It indicates the presence of significant antihypoxant properties in the compound.

\section{REFERENCES}

1. Агаджанян Н.А., Елфімов А.І. Функиї̈ організму в умовах гіпоксії та гіперкапнї. - М., 2006. - 197 с.

2. Гипоксия. Адаптация, патогенез, клиника. Руководство для врачей. // Под общ. ред. Ю.Л.Шевченко. С.Пб.: ООО «ЭЛБИ-С.Пб.», 2000. - 384 с.

3. Зайцев В.Г., Островский О.В., Закревский В.И. // Эксперим. и клин. фармакол. - 2003. - №4. - С. 66-77.

4. Использование лабораторных животных в токсикологическом эксперименте: Метод. рекоменд. // Под ред. проф., акад. РАМН П.И.Сидорова. - Архангельск, 2002.

5. Лосєв Н.І., Хитров Н.К., Грачов С.В. Патофізіологія гіпоксичних станів та адаптації організму до zіпоксї. - M., 2010. - $182 \mathrm{c}$.

6. Лук'янчук В.Д., Савченкова Л.В., Немятих О.Д., Радіонов В.М. Пошук та експериментальне вивчення потениійних антигіпоксичних засобів: Метод. рекоменд. - К.: ДФЦ МОЗ Украӥни, 2002. - 27 с.

7. Машковский М.Д. Лекарственные средства / М.Д. Машковский. - 16-е изд., перераб., испр. и доп. - М.: Новая волна, 2010. - 1216 с.

8. Методичні вказівки по доклінічному вивченню лікарських засобів / Під ред. А.В.Стефанова. - К., 2001. $-567 c$. 
9. Caro A.A., Cererbum A.I. // Ann. Rev. Pharmacol. Toxicol. - 2004. - Vol. 44. - P. 27-42.

10. Porter S.N., Howard G.S., Butler R.N. // Eur. J. of Pharmacol. - 2000. - №397. - P. 1-9.

\section{ВИВЧЕННЯ АНТИГІПОКСИЧНОЇ АКТИВНОСТІ 1-ФЕНЕТИЛ-5,7-ДИГІДРО- 1Н-ПІРОЛО[2,3-d]ПІРИМІДИН-2,4,6-ТРИОНУ НА РІЗНИХ МОДЕЛЯХ ГІПОКСІЙ О.В.Севрюков, В.А.Волковой, О.В.Колісник, К.М.Ситнік}

Ключові слова: гіпоксія; 1-френетил-5, 7-дигідро-1Н-піроло[2,3-d]піримідин-2,4,6-трион; антигіпоксант мексидол

Розповсюдження гіпоксичних станів є наслідком порушення мозкового, коронарного та перифреричного кровообігу, що потребує подальшого пошуку речовин, які здатні зменшувати негативний вплив гіпоксії на тканини, підвищуючи їх стійкість до гіпоксії. Представлені дослідження антигіпоксичної активності 1-фенетил-5, 7-дигідро-1Н-піроло[2, 3-d]піримідин2,4,6-триону (умовна назва «Дезапур») на різних моделях гіпоксій (гемічній, гіперкапнічній, гістотоксичній та гіпобаричній) у співставленні з препаратом порівняння - антигіпоксантом мексидолом. Дезапур у дозі 10 мг/кг та мексидол у дозі 100 мг/к己 проявили виражену антигіпоксичну активність на всіх видах гіпоксій по відношенню до контролю - на гемічній гіпоксії в 2,09 та 1,82, на гіперкапнічній - в 2,35 та 2,29, на гістотоксичній - в 2,04 та 1,9, на гіпобаричній - в 3,06 та 2,72 рази відповідно.

\section{ИЗУЧЕНИЕ АНТИГИПОКСИЧЕСКОЙ АКТИВНОСТИ 1-ФЕНЕТИЛ-5,7-ДИГИДРО-1Н- ПИРРОЛО[2,3-d]ПИРИМИДИН-2,4,6-ТРИОНА НА РАЗНЫХ МОДЕЛЯХ ГИПОКСИЙ А.В.Севрюков, В.А.Волковой, Е.В.Колесник, К.М.Сытник}

Ключевые слова: гипоксия; 1-френетил-5,7-дигидро-1Н-пирроло[2,3-d]пиримидин-2,4,6трион; антигипоксант мексидол

Распространение гипоксических состояний яөляется следствием нарушения мозгового, коронарного и перифрерического кровообращения, что требует дальнейшего поиска веществ, способных уменьшать негативное влияние гипоксии на ткани, повышая их устойчивость к гипоксии. Представлены исследования антигипоксической активности 1-френетил-5,7дигидро-1Н-пирроло[2,3-d]пиримидин-2,4,6-триона (условное название «Дезапур») на разных моделях гипоксий (гемической, гиперкапнической, гистотоксической, гипобарической). Препарат сравнения - мексидол. Дезапур в дозе 10 мг/кг и мексидол в дозе 100 мг/кг проявили выраженную антигипоксическую активность на всех видах гипоксий по отношению к контролю - на гемической гипоксии в 2,09 и 1,82, на гиперкапнической - в 2,35 и 2,29, на гистотоксической - в 2,04 и 1,9, на гипобарической - в 3,06 и 2,72 раза соответственно. 